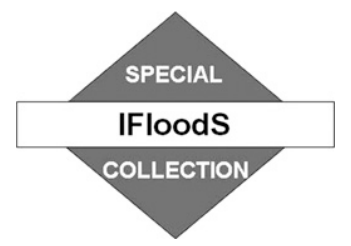

\title{
Atmospheric Rivers and Rainfall during NASA's Iowa Flood Studies (IFloodS) Campaign*
}

\author{
Munir A. Nayak, Gabriele Villarini, And A. Allen Bradley \\ IIHR-Hydroscience \& Engineering, The University of Iowa, Iowa City, Iowa
}

(Manuscript received 23 September 2014, in final form 31 August 2015)

\begin{abstract}
Atmospheric rivers (ARs) play a major role in causing extreme precipitation and flooding over the central United States (e.g., Midwest floods of 1993 and 2008). The goal of this study is to characterize rainfall associated with ARs over this region during the Iowa Flood Studies (IFloodS) campaign that took place in April-June 2013. Total precipitation during IFloodS was among the five largest accumulations recorded since the mid-twentieth century over most of this region, with three of the heavy rainfall events associated with ARs. As a preliminary step, the authors evaluate how well different remote sensing-based precipitation products captured the rainfall associated with the ARs and find that stage IV is the product that shows the closest agreement to the reference data. Two of the three ARs during IFloodS occurred within extratropical cyclones, with the moist ascent associated with the presence of cold fronts. In the third AR, mesoscale convective systems resulted in intense rainfall at many locations. In all the three cases, the continued supply of warm water vapor from the tropics and subtropics helped sustain the convective systems. Most of the rainfall during these ARs was concentrated within $\sim 100 \mathrm{~km}$ of the AR major axis, and this is the region where the rainfall amounts were highly positively correlated with the vapor transport intensity. Rainfall associated with ARs tends to be larger as these events mature over time. Although no major diurnal variation is detected in the AR occurrences, rainfall amounts during nocturnal ARs were higher than for ARs that occurred during the daytime.
\end{abstract}

\section{Introduction}

The National Aeronautics and Space Administration (NASA) launched a field measurement campaign called Iowa Flood Studies (IFloodS) during April-June 2013 in eastern Iowa in collaboration with the Iowa Flood Center (IFC) at the University of Iowa. The goal of this field campaign was to evaluate satellite estimates of rainfall and other hydrometeorological quantities, particularly from the $\mathrm{Ku}-\mathrm{Ka}$ radar similar to the one carried on board of the Global Precipitation Measurement (GPM; Hou et al. 2014) core satellite.

\footnotetext{
* Supplemental information related to this paper is available at the Journals Online website: http://dx.doi.org/10.1175/JHM-D-140185.s1.

Corresponding author address: Gabriele Villarini, IIHRHydroscience \& Engineering, The University of Iowa, 306 C. Maxwell Stanley Hydraulics Laboratory, Iowa City, IA 52242. E-mail: gabriele-villarini@uiowa.edu
}

Our study focuses on atmospheric rivers (ARs) and rainfall during the IFloodS period. ARs are narrow (less than $400 \mathrm{~km}$ in width) and long $(1000+\mathrm{km}$ in length) regions in the lower levels of the troposphere that transport large amounts of water vapor from the tropics and extratropics (Newell et al. 1992; Newell and Zhu 1994). In extratropical cyclones, ARs generally form in the warm sector in the presence of low-level jets (LLJs) ahead of cold fronts. Because of the presence of warm moist air and strong winds, under suitable lifting mechanisms (e.g., orographic, frontal, convective, and dynamic) ARs can lead to heavy rainfall events. These events have been linked to intense rainfall and flooding over many midlatitude regions, in particular over Europe (see, e.g., Lavers et al. 2011, 2012; Lavers and Villarini 2013a) and the U.S. West Coast (Ralph et al. 2004, 2006; Neiman et al. 2008). Apart from being a major flood agent, ARs can bring beneficial rains that replenish water resources, and in some cases, help end long-term droughts (Dettinger et al. 2011; Dettinger 2013; Ralph et al. 2013; Lavers and Villarini 2015a). 
Over the central United States, a necessary condition for the occurrence of major heavy rainfall events leading to floods is the presence of moist air advected by the Great Plains LLJ from oceanic sources, including the tropical Atlantic, the Gulf of Mexico, and the Caribbean Sea (Dirmeyer and Kinter 2009, 2010; Nakamura et al. 2013). In some cases, flood-producing heavy rainfall events can additionally involve water vapor transported from the eastern tropical Pacific via ARs. For example, Moore et al. (2012) found that ARs bringing water vapor from the eastern tropical Pacific and Caribbean Sea led to the flooding in Kentucky and Tennessee in May 2010. Unlike floods over the U.S. West Coast, which primarily result from rainfall due to orographic lifting of moist air, over the central United States mesoscale convection and frontal lifting in extratropical cyclones are generally the primary agents leading to heavy rainfall (e.g., Anderson and Arritt 2001; Dirmeyer and Kinter 2010). Since LLJ frequency over the central United States is high in spring and summer (Bonner 1968), it is not surprising that the majority of the heavy rainfall and flooding events over the region occur in the same seasons (Villarini et al. 2011b; Stevenson and Schumacher 2014). AR frequency, on the other hand, is evenly distributed within all seasons except for the summer when AR frequency is the lowest (Lavers and Villarini 2013b), likely because of the decreased equator-to-pole temperature gradient that results in lower baroclinic wave activity. The connection between ARs and flooding over the central United States was recently assessed by Lavers and Villarini (2013b). They found that during the period 1979-2011, in over $60 \%$ of the basins studied, five or more of the top 10 annual maxima were associated with ARs, including the two most destructive events, the great flood of 1993 (e.g., Kunkel et al. 1994) and the June 2008 flood (e.g., Budikova et al. 2010; Dirmeyer and Kinter 2010; Smith et al. 2013). Mesoscale convective systems (MCSs) can often produce heavy rainfall events over the central United States in spring and summer (Schumacher and Johnson 2005, 2006). These events develop in association with a southerly LLJ advecting warm, moist air and a southwesterly upper-level jet advecting dry air, resulting in a deep layer of convective instability (Maddox et al. 1979; Moore et al. 2003).

The primary objective of the IFloodS campaign was to provide integrated hydrologic ground validation of satellite-based rainfall to support remote sensing and hydrologic applications. This campaign has the potential to enhance our understanding of flooding mechanisms and to improve hydrologic modeling, which ultimately can improve the spatiotemporal predictions of floods. This study aims to complement the IFloodS campaign by providing a synoptic and mesoscale analysis of the prominent atmospheric features (such as ARs) that were present during some of the rainfall events during the IFloodS period. Overall, six intense rainfall events (24-h return period larger than 50 years) occurred during the IFloodS period in eastern Iowa, some of them causing flash floods in many parts of the region (e.g., the 17 April flash flood in Iowa City and the 30 May flood in Des Moines). Because of these high rainfall amounts and potential strong link between ARs and heavy rainfall over the central United States, it is reasonable to consider that some of the heavy rainfall events during IFloodS may have been associated with ARs. Quantifying the contribution from ARs is one of the primary objectives of the paper. Furthermore, to the best of our knowledge the distribution of rainfall accompanying ARs and its relationship with the strength of moisture transport within ARs over the central United States are not known yet. With these knowledge gaps in mind, we address the following questions:

1) What is the AR contribution to the total rainfall during the IFloodS period?

2) What are the physical mechanisms responsible for heavy rainfall during this period?

3) What are the characteristics (e.g., relationship between the strength of the AR and rainfall, distribution around AR's major axis, and latitudinal and diurnal dependence) of rainfall during AR events?

The rest of the paper is organized as follows. In section 2 , the data and methods used in this study are explained. Results are provided in section 3. Conclusions and future research directions are provided in section 4 .

\section{Data and methods}

The first step is the identification of ARs during the IFloodS period (from 10 April to 15 June 2013). Many previous studies employed column integrated water vapor (IWV) to identify ARs (see, e.g., Ralph et al. 2006; Dettinger et al. 2011); here we use integrated vapor transport (IVT) to identify these events because it was found to better capture major AR features (e.g., strong water vapor transport, narrow and elongated structure) than IWV (Nayak et al. 2014; Lavers and Villarini 2015a). Moreover, IVT was also found to be more strongly related to rainfall during AR events (Rutz et al. 2014; Lavers and Villarini 2015a,b). IVT magnitude $\left(\mathrm{kg} \mathrm{m}^{-1} \mathrm{~s}^{-1}\right)$ is calculated from specific humidity and wind speed in the atmosphere as follows:

$$
\mathrm{IVT}=\sqrt{\left(\frac{1}{g} \int_{\text {surface }}^{300} q u d p\right)^{2}+\left(\frac{1}{g} \int_{\text {surface }}^{300} q v d p\right)^{2}}
$$


Here, $q, u$, and $v$ are specific humidity $\left(\mathrm{kg} \mathrm{kg}^{-1}\right)$ and zonal and meridional wind components $\left(\mathrm{m} \mathrm{s}^{-1}\right)$, respectively; $g$ is the acceleration due to gravity (equal to $9.81 \mathrm{~m} \mathrm{~s}^{-2}$ ); and $p$ is pressure. We estimated IVT using a numerical approximation of the integrals with layeraveraged $q, u$, and $v$ from NASA's Modern-Era Retrospective Analysis for Research and Applications (MERRA; Rienecker et al. 2011) dataset for the period from 10 April to 15 June 2013 for pressure levels from the surface to $300 \mathrm{hPa}$. MERRA provides data with 6-h temporal resolution, $0.5^{\circ} \times 0.667^{\circ}$ horizontal grid resolution, and at 72 vertical levels from the surface to $0.01 \mathrm{hPa}$. We used 28 vertical levels from the surface to $300 \mathrm{hPa}$.

To identify ARs using IVT, we used the methodology developed by Lavers and Villarini (2013b) with minor adjustments. In the first step, starting at $40^{\circ} \mathrm{N}$ latitude, we determine the maximum IVT value between $85^{\circ}$ and $100^{\circ} \mathrm{W}$. If the maximum is above a prespecified threshold, the longitude of the maximum value is recorded, and we move to $39.5^{\circ} \mathrm{N}$, the grid point south of the starting point. The threshold used here is $550 \mathrm{~kg} \mathrm{~m}^{-1} \mathrm{~s}^{-1}$, which is approximately the 85 th percentile threshold by Lavers and Villarini (2013b) for the month of May over the central United States. At $39.5^{\circ} \mathrm{N}$, the maximum IVT value is identified. If its location is within one grid point either to the east or to the west of the longitude of the location at $40^{\circ} \mathrm{N}$, we continue searching southward. This displacement condition is to enforce spatial continuity in the AR. If all the points from $40^{\circ}$ to $30.5^{\circ} \mathrm{N}$ have maximum IVT values exceeding the threshold and if they satisfy the displacement condition, then we consider this an AR time step. The same procedure is repeated from south to north to confirm the correct latitude-longitude of the maximum IVTs. We refer to the AR major axis as the collection of points with the maximum IVT values exceeding the threshold from $40^{\circ}$ to $30.5^{\circ} \mathrm{N}$. Most of the AR time steps had the same major axis whether one starts at $40^{\circ}$ or $30.5^{\circ} \mathrm{N}$, but four out of $17 \mathrm{AR}$ time steps had differences due to the existence of secondary maxima. In each of these cases, we selected the AR major axis by visual examination of the IVT maps. The visual examination to select AR major axes and additional search from south to north were the two modifications that we made to the methodology by Lavers and Villarini (2013b). The $40^{\circ} \mathrm{N}$ latitude is chosen to make sure that ARs travel deep into the central United States, and a length from $40^{\circ}$ to $30.5^{\circ} \mathrm{N}$ (approximately $950 \mathrm{~km}$ ) is chosen as the minimum length requirement. A total of 17 six-hourly AR time steps are identified as ARs. The 17 AR steps make up three persistent (duration of more than $18 \mathrm{~h}$ ) ARs, two with six time steps (one from 0600 UTC April 10 to 1200 UTC April 11 and another from 0000 UTC April 18 to 0600 UTC April 19), and one with five time steps (from 1200 UTC May 29 to 1200 UTC May 30).

The contribution of ARs to the total rainfall during IFloodS is estimated based on remote sensing rainfall estimates and rain gauge measurements from different data sources. The datasets are the Tropical Rainfall Measuring Mission (TRMM) Multisatellite Precipitation Analysis (TMPA) for research [TRMM 3B42, version 7 (TRMM 3B42-V7)] and for real time [TRMM 3B42RT, version 7 (TRMM 3B42RT-V7)] (Huffman et al. 2007), the National Oceanic and Atmospheric Administration (NOAA)/Climate Prediction Center (CPC) morphing technique (CMORPH; Joyce et al. 2004), Precipitation Estimation from Remotely Sensed Information Using Artificial Neural Networks (PERSIANN; Sorooshian et al. 2000), and NOAA/National Centers for Environmental Prediction (NCEP) product stage IV (Lin and Mitchell 2005). Except for stage IV, all the datasets are 3-hourly and with a horizontal grid resolution of $0.25^{\circ} \times 0.25^{\circ}$. Stage IV has a finer spatial and temporal resolution (hourly and about $4 \mathrm{~km} \times 4 \mathrm{~km}$ ). The total rainfall and the contribution of ARs from all these products are compared and evaluated with respect to the CPC's Unified gauge daily dataset (Higgins et al. 2000), which we use as a reference dataset. It is based on rain gauge measurements from a number of networks and has a spatial resolution of $0.25^{\circ}$. We defined the AR rainfall as the rainfall within a 2 decimaldegree buffer $(\sim 200 \mathrm{~km})$ of the delineated AR major axis during the time periods from 1200 UTC April 10 to 1200 UTC 11 April, from 1200 UTC April 17 to 1200 UTC April 19, and from 1200 UTC May 29 to 1200 UTC May 31.

\section{Results and discussion}

\section{a. Evaluation of remote sensing products}

The first step is the examination of the capability of different remote sensing rainfall estimates in characterizing rainfall during the IFloodS campaign. Figure 1a shows the accumulated rainfall during the study period based on the CPC dataset, while Figs. 1b and $1 \mathrm{c}$ show the AR contributions. This was a very wet period, with some of the largest rainfall accumulations over the 1948-2013 period. Figure 1d shows the rank of rainfall amount during this period as compared to the 66-yr record from 1948 to 2013. Most of the regions in the central United States received anomalously high rainfall amounts (i.e., ranked in the top five wettest seasons) leading to flooding over the 

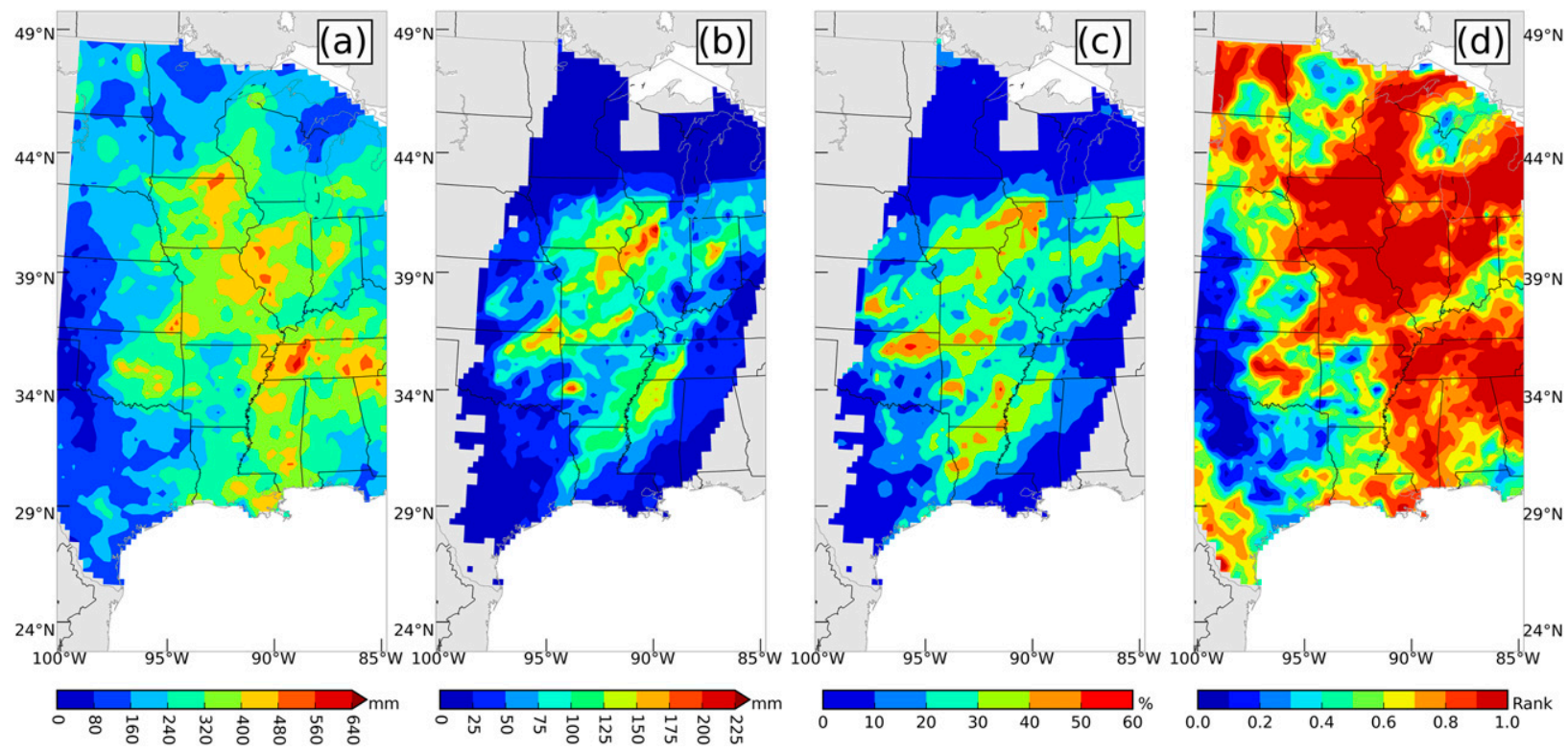

FIG. 1. Contribution of ARs to the total rainfall during the IFloodS campaign based on CPC rainfall data. (a) Total rainfall (mm) over the period from 10 Apr to 15 Jun 2013. (b) Rainfall (mm) associated with ARs. (c) Percentage (\%) of total rainfall associated with ARs. (d) Rank of the amount of rainfall during IFloodS period in a 66-yr record (1 means the wettest period, 0 the driest).

study area. ARs account for more than $50 \%$ of the total rainfall in isolated areas as far north as Iowa and Illinois and as far south as Oklahoma and Arkansas (Fig. 1c). These results, and the ones in the following sections, provide empirical evidence that ARs are agents for heavy rainfall and flooding over the central United States.

Before characterizing the rainfall associated with ARs, we need to identify the most suitable rainfall product. Because the stage IV precipitation estimates are obtained from a number of weather radars that are part of the Next Generation Weather Radar (NEXRAD) network and from hourly and 6-hourly surface rain analysis data of 12 National Weather Service (NWS) River Forecasting Centers (RFCs) over the continental United States, our a priori expectation is that stage IV will be the product that most closely resembles the CPC data. Similarly, we expect TRMM 3B42RT-V7 to perform well because of the monthly bias correction applied to this product. However, it is difficult to establish a priori how much worse the performance of the non-rain-gauge-corrected products will be and the role of rain gauge adjustment. Figure 2 shows the results for the different remote sensing products described in section 2. Overall, there is a large difference in the spatial distribution of rainfall in PERSIANN, CMORPH, and TRMM 3B42RT-V7 compared to CPC (Fig. 1). For example, PERSIANN, CMORPH, and TRMM 3B42RT-V7 overestimate the medium to high rainfall values (areas with rainfall in excess of 350-400 $\mathrm{mm}$ ) over large parts of Oklahoma and underestimate the high rainfall (areas with rainfall in excess of $500 \mathrm{~mm}$ ) in the eastern part of Tennessee. Stage IV rainfall amounts and spatial distribution match closely those of CPC. TRMM 3B42-V7 follows stage IV in terms of closeness to $\mathrm{CPC}$, likely because it is the only satellite product that undergoes monthly bias correction with respect to rain gauges. The better representation of the observational data by stage IV is also portrayed in the comparisons of AR rainfall and its fractional contributions to the total rainfall.

Figure 3 shows box plots of the differences between rainfall from CPC and the different products. Figures $3 \mathrm{a}$ and $3 b$ show daily differences in the rainfall averaged over the region from $30^{\circ}$ to $40^{\circ} \mathrm{N}$ and from $85^{\circ}$ to $100^{\circ} \mathrm{W}$ between each of the remote sensing products and CPC including zeros (Fig. 3a) and excluding zeros (Fig. 3b). Figures $3 \mathrm{c}$ and $3 \mathrm{~d}$ show the box plots of the gridcell differences between total IFloodS rainfall (Fig. 3c) and AR rainfall (Fig. 3d) from the remote sensing products and CPC. Stage IV has the lowest bias and the lowest spread followed by TRMM 3B42-V7. We have applied the Kolmogorov-Smirnov test to find the similarity between the daily rainfall distribution from CPC and each of the remote sensing products. The results in Fig. 1 in the supplemental material show that the stage IV daily rainfall distribution is similar to the CPC distribution over almost the entire central United States. Because of these results, and because of the high temporal and 

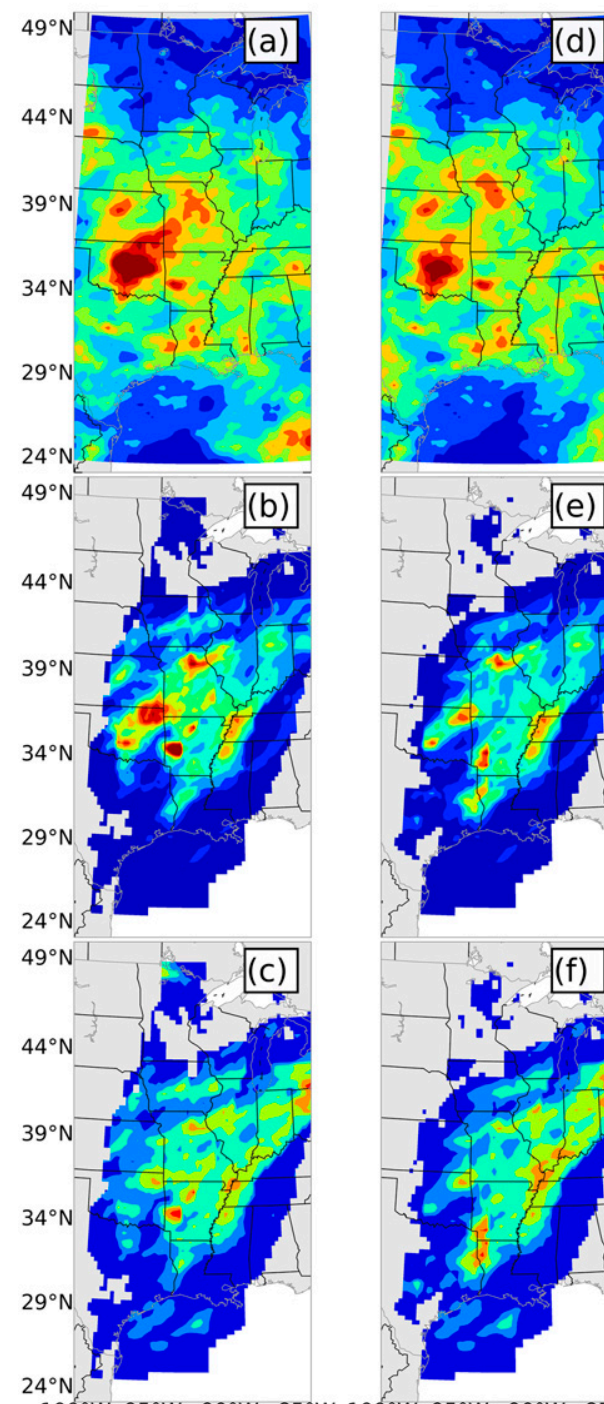

$100^{\circ} \mathrm{W} 95^{\circ} \mathrm{W} \quad 90^{\circ} \mathrm{W} \quad 85^{\circ} \mathrm{W} 100^{\circ} \mathrm{W} \quad 95^{\circ} \mathrm{W} \quad 90^{\circ} \mathrm{W} \quad 85^{\circ} \mathrm{W} \quad 100^{\circ} \mathrm{W} \quad 95^{\circ} \mathrm{W} \quad 90^{\circ} \mathrm{W} \quad 85^{\circ} \mathrm{W} \quad 100^{\circ} \mathrm{W} \quad 95^{\circ} \mathrm{W} \quad 90^{\circ} \mathrm{W} \quad 85^{\circ} \mathrm{W} \quad 100^{\circ} \mathrm{W} \quad 95^{\circ} \mathrm{W} \quad 90^{\circ} \mathrm{W} \quad 85^{\circ} \mathrm{W}$

FIG. 2. Comparison of different rainfall products: (a)-(c) PERSIANN, (d)-(f) CMORPH, (g)-(i) TRMM 3B42RT-V7, (j)-(1) TRMM 3B42-V7, and (m)-(o) stage IV data. Shown is the total accumulated rainfall ( $\mathrm{mm}$ ) during the IFloodS campaign (top), the rainfall (mm) associated with ARs (middle), and the percentage (\%) of total rainfall associated with ARs (bottom).

spatial resolution, we adopt stage IV data to characterize rainfall from ARs.

\section{b. Physical mechanisms responsible for rainfall during ARs}

The three ARs detected during IFloodS were associated with high rainfall amounts over much of the central United States. Figure 4 shows the rainfall maps during the ARs (from $3 \mathrm{~h}$ before the first time step of AR to $3 \mathrm{~h}$ after the last time step). The rainfall fields in these maps can be compared with Fig. 1a, suggesting that a substantial amount of rainfall during IFloodS was due to the three ARs. At some locations, about $30 \%$ of the IFloodS rainfall was during the presence of one AR. Of the three
ARs that developed over the central United States during the IFloodS campaign, the weather systems of the first two (from 0600 UTC April 10 to 1200 UTC April 11 and from 0000 UTC April 18 to 0600 UTC April 19) are extratropical cyclones; these two ARs both have a rainfall pattern (Figs. 4a,b) related to the mesoscale rainbands observed in extratropical cyclones (McMurdie and Houze 2006; Houze 2014). During the third AR, MCSs resulted in contiguous high rainfall amounts over Kansas and northern Oklahoma.

We first briefly describe the extratropical weather systems associated with the first two ARs. The weather system corresponding to the third AR is described later in this section. Figures 5 and 6 show snapshots of the 

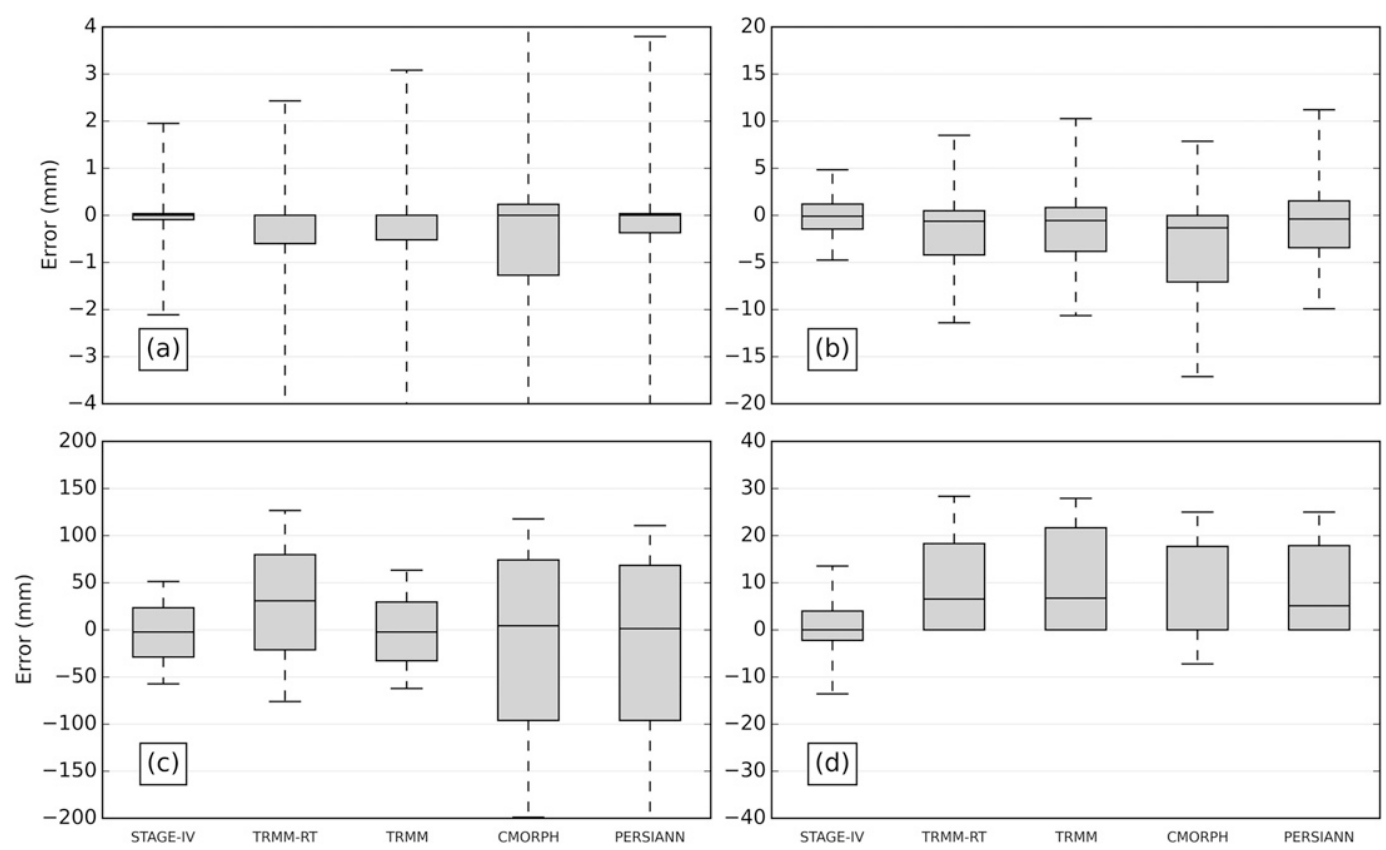

FIG. 3. Box plots of the differences between CPC and remote sensing products. (a) Daily differences for rainfall values over the region $30^{\circ}-40^{\circ} \mathrm{N}, 85^{\circ}-100^{\circ} \mathrm{W}$. (b) As in (a), but for all days except for those with zero rainfall. (c) Differences in total rainfall between CPC and the remote sensing product during IFloodS. (d) Differences in AR rainfall over the entire study period. Whiskers represent 10th and 90th percentiles; the box represents the interquartile range (25th and 75th percentiles), with the line inside showing the median (50th percentile).

weather systems at 1800 UTC 10 April and 1800 UTC 18 April, respectively. In Figs. 2-7 in the supplemental material, we provide this kind of information for all the AR days. The two weather systems in Figs. 5 and 6 are fairly similar, although the weather corresponding to Fig. 6 seems more organized with a stronger and better-defined cyclone than what is shown in Fig. 5. For the purpose of conciseness, we only describe the weather system corresponding to the AR in Fig. 6 (we call this the 18 April AR event). Geopotential heights at $850 \mathrm{hPa}$ (contours in Fig. 6a) and surface pressure (contours in Fig. 6d) show the presence of a low near eastern Iowa. At the 850-hPa level, the slow-moving lee trough over much of the Great Plains and a subtropical ridge over the Atlantic near the U.S. East Coast maintained poleward advection of warm moist air from the Gulf of Mexico. At higher levels, an advancing shortwave trough and cutoff low can be seen at $500 \mathrm{hPa}$ (geopotential height contours in Fig. 6c), affecting the surface low and steering it northeastward. However, as the wave progresses, the location of the 500-hPa cutoff low eventually coincides with the location of the surface low pressure center (Fig. 5 in the supplemental material), indicating the mature phase of the system.

The steep gradient of equivalent potential temperature $\theta_{e}$ (contours in Fig. 6b) over Iowa and Missouri and extending to Texas defines the position of the surface cold front that was present during this AR. In Fig. 6b, winds to the east of the front have a strong southerly component, whereas the winds just to the west of the front have a prominent westerly component. The position of the AR (large IVT values in Fig. 6c and large IWV values in Fig. 6a) is marginally to the east of the cold front in the warm sector (shaded regions in Figs. $6 \mathrm{a}, \mathrm{c})$. To the east of this front, the air is uniformly warm and moist, and a narrow band of ascent takes place (Fig. 6b) associated with convective rainfall coincident with the surface cold front. Widespread heavy rainfall can be seen in the earlier period of AR (0000-0600 UTC 18 April) along the warm front across most of the upper Midwest (Fig. 4 in the supplemental material). Similar to a typical AR and extratropical cyclone system, sinking of cold and dry air takes place behind the cold front (e.g., Carlson 1980; Browning 1997; Schultz 2001; Catto et al. 2010). This cold air is advected by winds that are directed equatorward and to the west of cold front.

As in a typical extratropical cyclone, the baroclinic wave and its associated surface low pressure center and cold front intensified and propagated eastward; as a result, the AR produces continuous heavy precipitation along its path (Figs. 4, 5 in the supplemental material). In Fig. 6d, the narrow band of heavy rainfall along the cold front due to convection is persistent during all the 

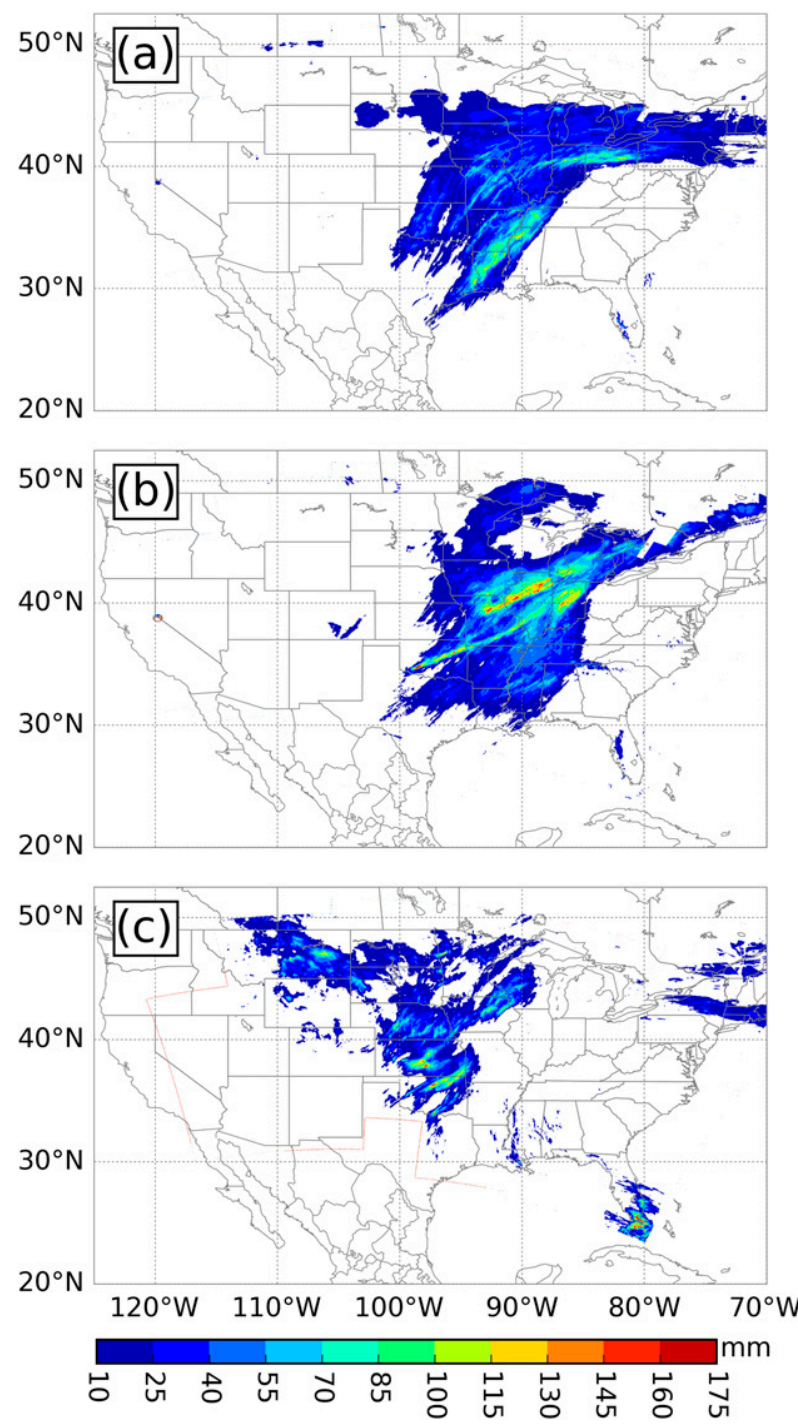

FIG. 4. Accumulated rainfall for the three ARs during the IFloodS period based on stage IV precipitation estimates: (a) 10 Apr AR, (b) 18 Apr AR, and (c) 30 May AR. For all the three ARs, the accumulations are based on rainfall from $3 \mathrm{~h}$ before the first $A R$ time step to the $3 \mathrm{~h}$ after the last AR time step.

AR's time steps. The circular structure of rainfall around the low pressure center over Iowa is related to the spiral ascent of warm moist air and descent of cold dry air that results because of cyclonic flow in and around the low pressure system. Figure 6e shows the skew (temperature $T$ ) $-\log p$ diagram near Little Rock, Arkansas, at 1500 UTC 18 April. Near-saturated and unstable conditions prevailed in the layer from the surface to $620 \mathrm{hPa}$ with a convective available potential energy (CAPE) of $1056 \mathrm{~J} \mathrm{~kg}^{-1}$. Precipitation occurred in the form of rainfall from the surface to the higher levels as indicated by the high freezing level $(\sim 3.6 \mathrm{~km})$. The veering of the winds with height at lower levels suggests that the near-surface southerlies are advecting warm, moist air from the Gulf of Mexico northward, based on a geostrophic flow approximation and the thermal wind relationship. Aloft $(\sim 550-500 \mathrm{hPa})$ a dry stable temperature inversion layer shows the presence of a frontal zone in the upper levels. At higher levels $(<400 \mathrm{hPa})$, strong westerly winds dominate and the atmosphere remains stable and unsaturated. The skew $T-\log p$ diagram of the AR at 1800 UTC 10 April is shown in Fig. 5e. The lower levels $(\sim 920-780 \mathrm{hPa})$ are moist and unstable, with a high corresponding CAPE value of $2476 \mathrm{~J} \mathrm{~kg}^{-1}$. The atmospheric conditions in this case are similar to the AR on 18 April; however, in this case, a dry capping inversion occurs at a lower level ( $\sim 700$ as opposed to $500 \mathrm{hPa}$ ).

The weather system corresponding to the third AR is shown in Fig. 7 and in Figs. 6 and 7 in the supplemental material. This AR was associated with a major tornado outbreak that began on 27 May in the U.S. Midwest and intensified on 29 and 30 May. The AR was driven by the anticyclonic flow around the Bermuda high, bringing warm moist air from the Gulf of Mexico into the central United States. During the initial time steps of the AR on 29 May, scattered rainfall was observed over most of the U.S. Midwest. As a weak upper-level disturbance approaches, a low pressure center forms near Nebraska. Large values of IWV and IVT (Figs. 7a,c) are present over most of the central United States, indicating the moist atmospheric conditions from the Gulf of Mexico all the way to the northern parts of the central United States. At lower levels, southerly winds advected warm and moist air from the Gulf of Mexico (presented in the next section). A 500-hPa trough was located over the Great Plains and intensified and propagated eastward (Fig. 7c and Figs. 6, 7 in the supplemental material). The presence of the AR for an extended period of time provided a continuous supply of warm moist air supporting the development of rainfall events and thunderstorms. These conditions favored the formation and sustainability of MCSs (Houze 2014) over Kansas. Figure 7e shows the skew $T-\log p$ diagram for 1200 UTC 30 May at Lamont, Oklahoma. The atmosphere in the lower levels is warm and at near saturation, with winds exceeding $25 \mathrm{~m} \mathrm{~s}^{-1}$. The winds from the surface to $750 \mathrm{hPa}$ veer from the south to the southwest, as warm air advection further destabilizes the atmosphere. Strong vertical wind shear was associated with the severe weather that impacted many locations in the U.S. Midwest. In particular, on 30 May, seven people were killed in Oklahoma because of tornadoes. Although a capping inversion exists at 1200 UTC, the CAPE and convective inhibition (CIN) values are $1850 \mathrm{~J} \mathrm{~kg}^{-1}$ and $-100 \mathrm{~J} \mathrm{~kg}^{-1}$, respectively, which indicate the 

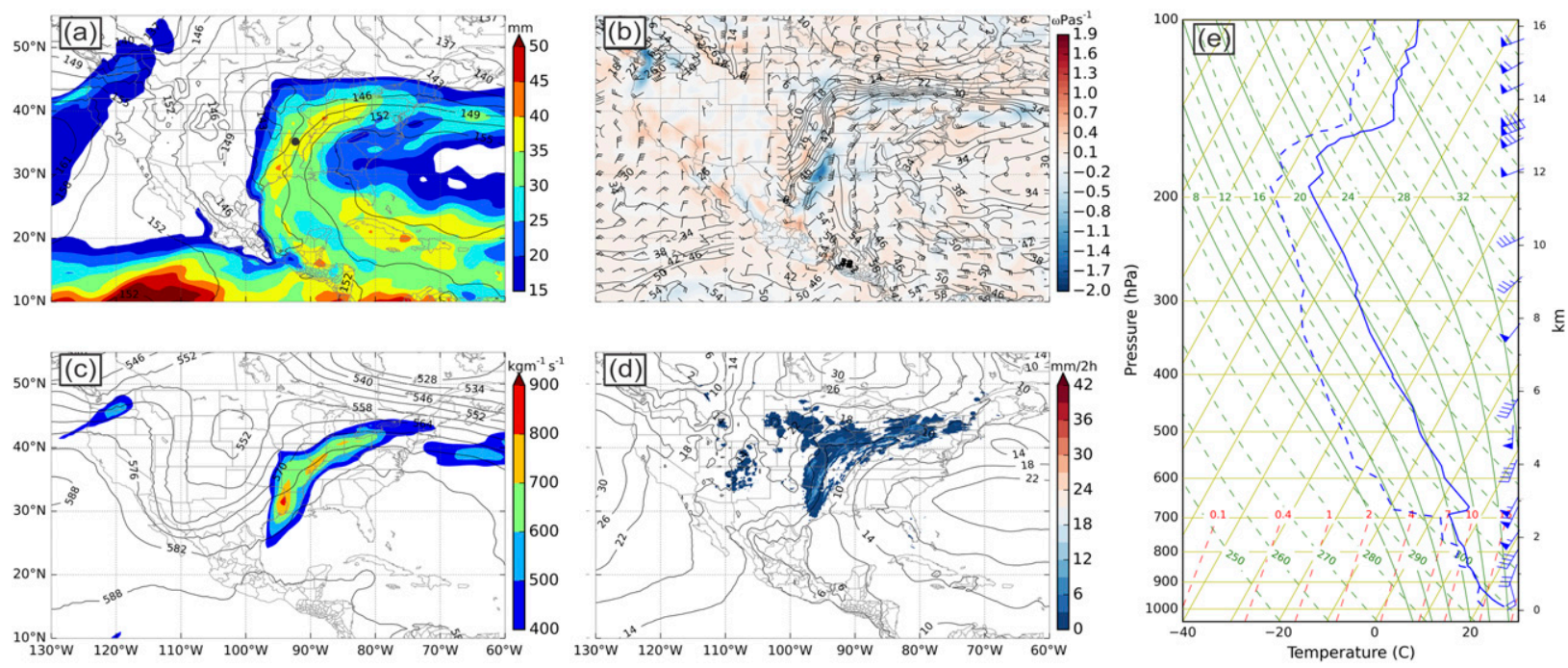

FIG. 5. Weather system prevalent at 1800 UTC 10 Apr 2013. (a) The 850-hPa geopotential height (dams; contours at an interval of 3 dams) and IWV (mm; shaded contours). (b) Vertical wind velocity [shaded; negative means ascent; based on ERA-Interim (Dee et al. 2011)], wind barbs $\left(\mathrm{m} \mathrm{s}^{-1}\right.$; half barbs $=2.5 \mathrm{~m} \mathrm{~s}^{-1}$, full barbs $=5 \mathrm{~m} \mathrm{~s}^{-1}$, and pennant $\left.=25 \mathrm{~m} \mathrm{~s}^{-1}\right)$, and equivalent potential temperature $\theta_{e}$ $\left({ }^{\circ} \mathrm{C}\right.$; contours at an interval of $\left.4^{\circ} \mathrm{C}\right)$. (c) The 500-hPa geopotential height (dams; contours at an interval of 3 dams) and IVT (kg m ${ }^{-1} \mathrm{~s}^{-1}$; shaded). (d) Mean sea level pressure [surface level pressure considered to be at $1000 \mathrm{hPa}$ (slp-1000)] (m; contours at interval of $40 \mathrm{~m}$ ), and 2-h stage IV cumulative rainfall (1700-1900 UTC 10 Apr 2013). (e) Skew T-log plot at 1800 UTC 10 Apr 2013. Vertical temperature is plotted as a solid line, dewpoint as a dashed line, and wind barbs are according to the convention used in Fig. 5 b. These results are for Little Rock, Arkansas (station ID 72340), and were obtained from the University of Wyoming's sounding archive. The black filled circle in (a) shows the location of the station.

atmosphere is conditionally unstable. With daytime heating and sufficient lifting to trigger thunderstorms, deep convection resulted in intense rainfall at this and many other locations across the U.S. Midwest.

A Lagrangian trajectory analysis was performed for the three ARs to find out the sources of air parcels and their properties along the trajectories. For the ARs on
10 and 18 April, parcels $1^{\circ} \times 1^{\circ}$ apart in the box encompassing $37^{\circ} \mathrm{N}, 86^{\circ} \mathrm{W}$ and $40^{\circ} \mathrm{N}, 90^{\circ} \mathrm{W}$ and ending at 0600 UTC 11 April and 1800 UTC 18 April, respectively, were traced backward. For the AR on 29 April, parcels in the box encompassing $37^{\circ} \mathrm{N}, 93^{\circ} \mathrm{W}$ and $40^{\circ} \mathrm{N}, 97^{\circ} \mathrm{W}$ and ending at 1200 UTC 30 May were traced. In all the three cases, the parcels were traced $72 \mathrm{~h}$ backward at
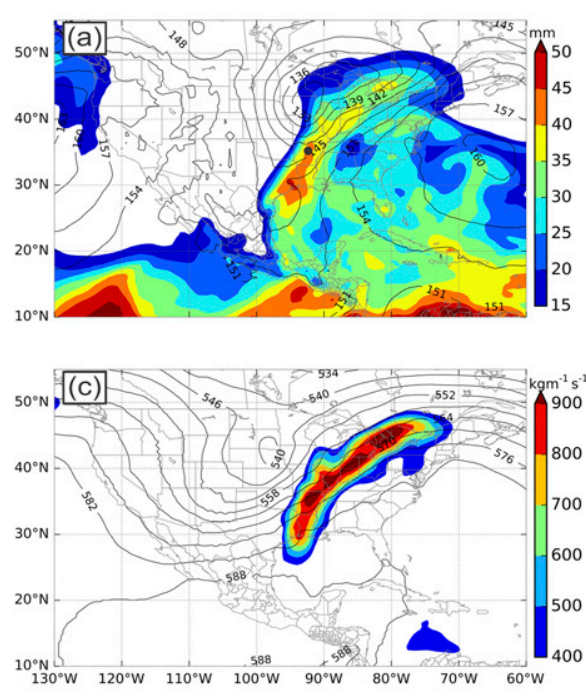
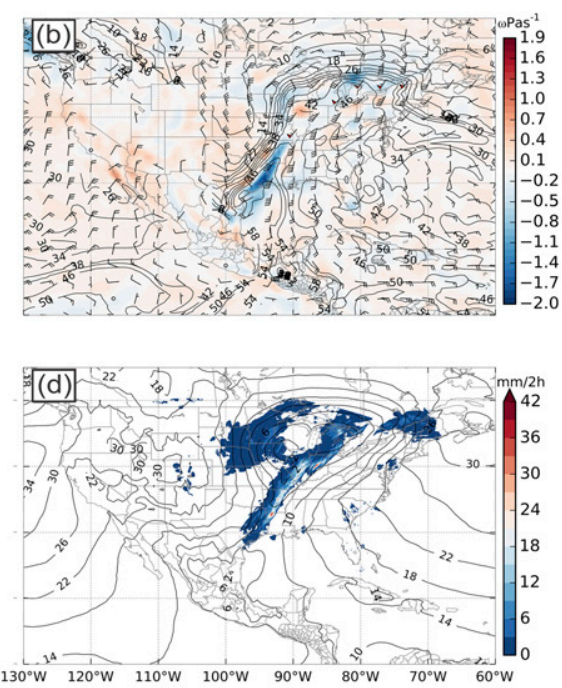

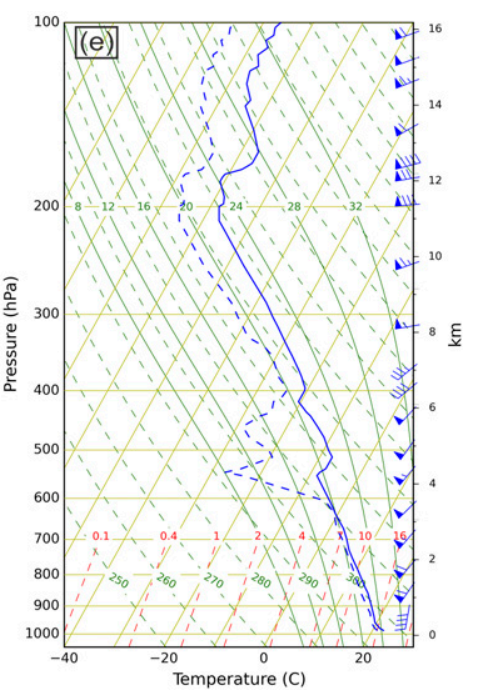

FIG. 6. As in Fig. 5, but for 1800 UTC 18 Apr 2013. Skew T-log plot is at 1500 UTC 18 Apr 2013. 

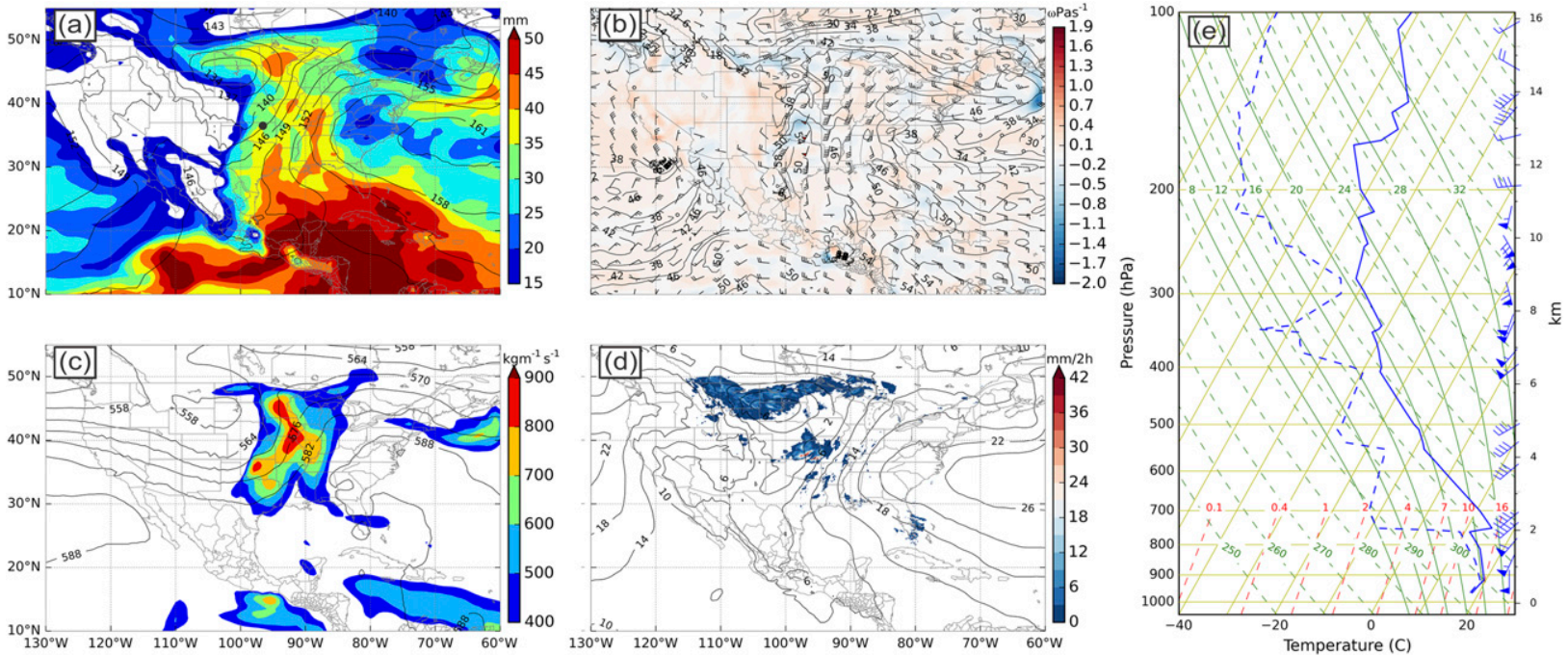

FIG. 7. As in Fig. 5, but for 1200 UTC 30 May 2013. Skew T-logp plot is at 1200 UTC 30 May 2013 with soundings taken at Lamont, Oklahoma (station ID 74646).

$1000(\sim 880), 4000(\sim 620)$, and $6000 \mathrm{~m} \mathrm{AGL}(\sim 500 \mathrm{hPa})$ levels. At these selected locations and times, IVT was relatively high with widespread concurrent rainfalls over the central United States. This analysis is similar to what was performed by Moore et al. (2012) and Neiman et al. (2014). In Figs. 8a-c, 1000 m AGL parcels mostly originated from the central or eastern Gulf of Mexico, although 84-h backward trajectory analysis (not shown here) shows that some parcels originated in the Caribbean Sea. Figures $8 \mathrm{~d}-\mathrm{f}$ show the average pressure and mixing ratio of the parcels along the trajectories. In all the three cases, the parcels gradually descended while entering the southern United States. These parcels remained moist throughout their trajectories (with relative humidity $60 \%-80 \%$ and mixing ratio $\left.8-12 \mathrm{~g} \mathrm{~kg}^{-1}\right)$. In the AR on 10 April low-level trajectory, there is a substantial increase in mixing ratio; however, along the trajectory the parcels exhibited a decrease in mixing ratio and a weak subsidence before entering the box from which the parcels were traced. As the parcels enter

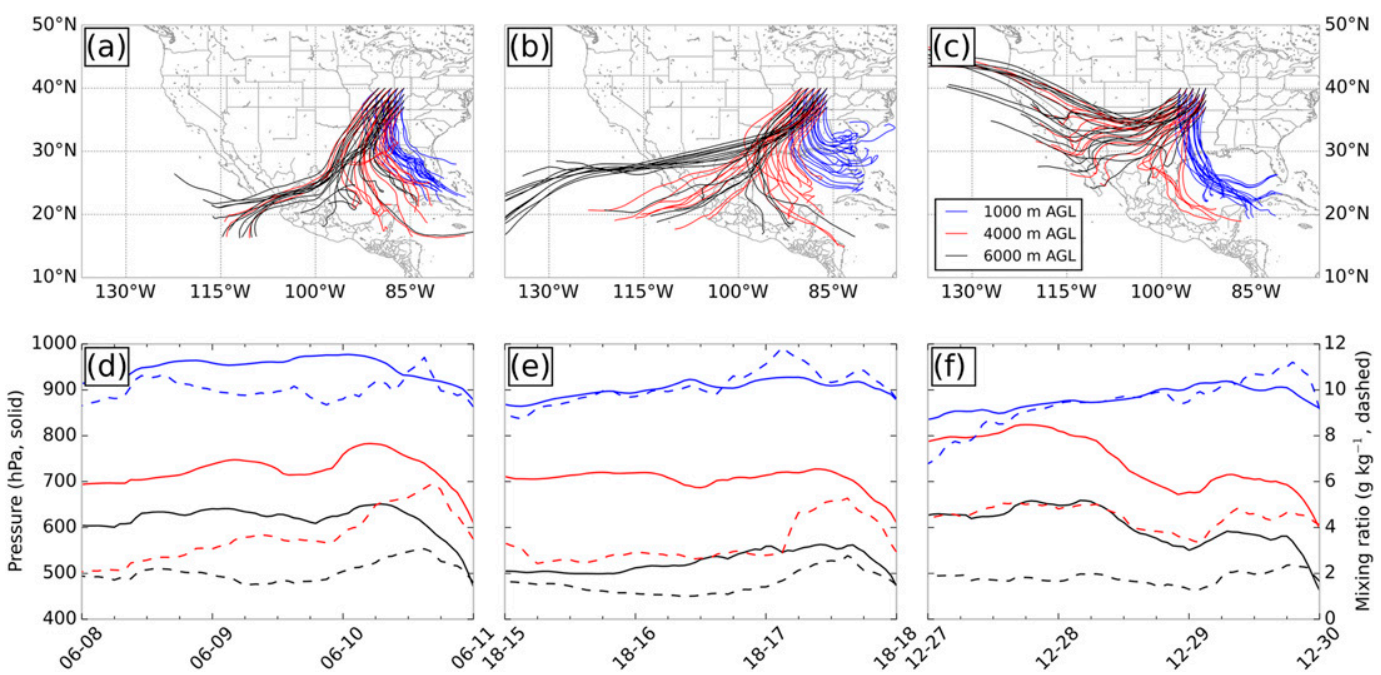

FIG. 8. Trajectory analysis of air parcels ending at (a),(d) 0600 UTC 11 Apr; (b),(e) 1800 UTC 18 Apr; and (c),(f) 1200 UTC 30 May for the three ARs. Shown are 72-h backward trajectories for the three ARs with parcels ending at 1000 (blue), 4000 (red), and $6000 \mathrm{~m}$ AGL (black) (top) and air pressure (solid) and mixing ratio (dashed) along the trajectories (bottom). The data in these plots are obtained from NARR using the Hybrid Single-Particle Lagrangian Integrated Trajectory (HYSPLIT) model (Draxler and Rolph 2015). See text for a detailed description. 
into the box, after an initial increase in the mixing ratio, a strong decrease in the mixing ratio and a moderate ascent, and relative humidity about $80 \%$, suggest significant rainout. In the lower-level parcels of ARs on 18 and 30 April, significant moisture is gained throughout the trajectory before entering the boxes. Similar to the AR on 10 April, a decrease in mixing ratio and ascent (with high relative humidity of $80 \%$ ) indicates substantial condensation and rainout. The majority of the parcels ending at $4000 \mathrm{~m}$ AGL originated over the eastern Gulf of Mexico; however, in the ARs on 18 April and 30 May, some parcels are advected from western Mexico and the western United States. Most of the parcels ending at $6000 \mathrm{~m}$ AGL originated from the western Pacific and southwestern United States. For the ARs on 10 and 18 April, parcels ending at 4000 and $6000 \mathrm{~m}$ AGL are dry (mixing ratio of $2-4 \mathrm{~g} \mathrm{~kg}^{-1}$ and relative humidity of $25 \%-35 \%$ ) with mild descent before entering the southern and central United States (from 1200 UTC 10 April to 0600 UTC 11 April in Fig. 8d and from 0000 to 1800 UTC 18 April in Fig. 8e). Here, mixing ratio and relative humidity increase rather abruptly and parcels ascend over a small period of time, suggestive of the lifting of moist air along the frontal boundary present during this AR. Similar conditions are observed in the AR on 30 May, except that parcels are initially lifted around the midpoint of their trajectory. This is perhaps due to the presence of high-elevation mountains over the western United States. After this, the parcels descend gradually, only to be lifted again toward the end of the trajectories (from 0000 to 1200 UTC 30 May in Fig. 8f), where relative humidity increases to $60 \%-80 \%$. At this stage, there is also a large decrease in the mixing ratio, indicating rainout with lifting in the presence of the cold fronts associated with the ARs. In all the three cases, noting that the upper-level trajectories were rather dry, most of the water vapor in the ARs originates from the northern tropics and subtropics over the Gulf of Mexico and the Caribbean, perhaps with some moisture generated over the terrestrial southern United States as depicted in Figs. 8d and 8e. Moore et al. (2012) also identified the Caribbean Sea and Gulf of Mexico as the predominant sources of moisture in the May 2010 heavy rainfall that resulted in flooding over Kentucky and Tennessee.

The IFloodS rainfall mechanisms for the first two ARs were similar to a major flooding event that happened on 1-2 May 2010 in Nashville, Tennessee, and surrounding areas. In this event, a low pressure system developed over the northern Great Plains, including eastern Canada [at the low pressure center, $850-\mathrm{hPa}$ geopotential height was $1230 \mathrm{~m}$; see Fig. 4b of Moore et al. (2012)]. In essence, this event was caused by the persistent presence of AR conditions, with its high IVT and high IWV values over the U.S. Midwest providing a constant source of precipitable water to the MCSs that developed over a couple of days (Moore et al. 2012). Although the low pressure systems during IFloodS ARs (e.g., 850-hPa geopotential height of $1340 \mathrm{~m}$ at the low pressure center on the 18 April AR) were not as strong as the 2010 Tennessee event (corresponding height of about $1200 \mathrm{~m}$ ), the synoptic features were similar; the low pressure system over the northern Great Plains and persistent AR conditions of the first two ARs resemble the 2010 Tennessee event. In their first MCS environment, Moore et al. (2012) observed two moist and unstable atmospheric layers with dry conditions aloft. In the second MCS, the lower layers were extremely moist with a convectively unstable layer just above $200 \mathrm{hPa}$ from the surface. In the ARs during IFloodS, moist unstable atmospheric conditions were observed only in the lower atmosphere, and in all the cases, the unstable layers were capped by a dry stable layer, followed by a dry conditionally stable layer. In essence, the mesoscale conditions present during the ARs in IFloodS were similar to the one that resulted in heavy flooding in Tennessee in May 2010 described in Moore et al. (2012).

\section{c. Rainfall characteristics in ARs}

The assessment of the distribution of rainfall around the AR major axis is one of the prime objectives of this paper. For each of the 17 AR time steps, we divide the area around the AR major axis into three regions. The closest region is within one longitude point from the major axis (i.e., $\pm 74 \mathrm{~km}$ from the major axis). The second region covers a distance from 74 to $150 \mathrm{~km}$ to the east and to the west of the major axis. The third and farthest region is from 150 to $370 \mathrm{~km}$ to the east and west of the major axis. The average rainfall within these regions is calculated $1 \mathrm{~h}$ before and $1 \mathrm{~h}$ after each AR occurrence time. We also calculate the Pearson and Spearman correlation coefficients between IVT and rainfall in these three regions. This is done as we suspect more IVT may lead to more rainfall.

The relationship between rainfall amount and distance from the AR major axis is shown in Fig. 9. Here, Spearman and Pearson correlation coefficients between IVT and rainfall are also plotted. The highest rainfall is observed in the region closest to the AR major axis, and then it decreases as we move farther away. Hence, most of the rainfall occurs within about $100 \mathrm{~km}$ of the AR major axis. This is likely because of higher IVT in this region, which in the presence of unstable conditions leads to condensation of water vapor and increased precipitation. The rainfall amounts tend to be the largest between $34.5^{\circ}$ and $37.5^{\circ} \mathrm{N}$, with a less marked latitudinal dependence as we move farther away from the AR major axis. 

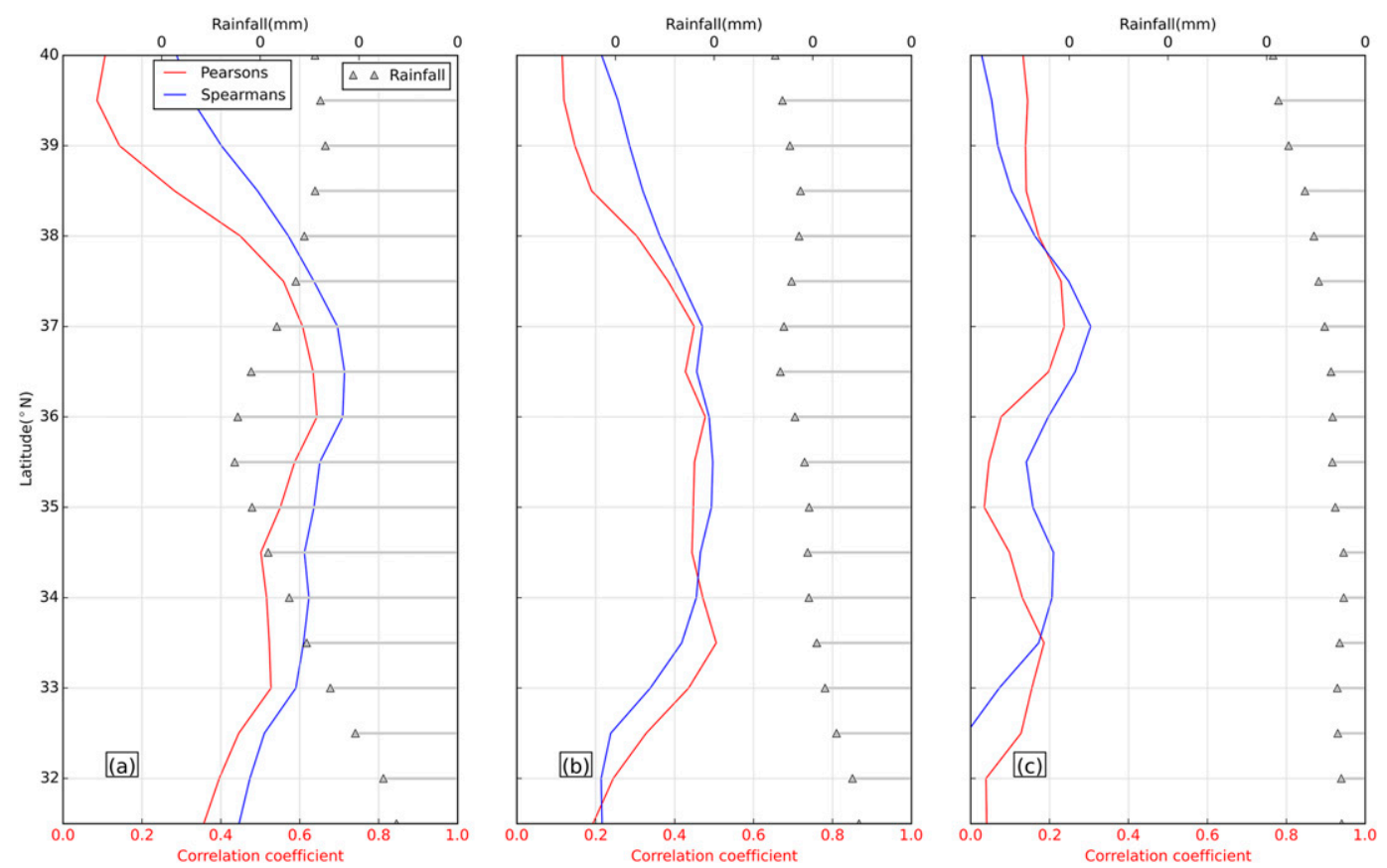

FIG. 9. Examination of the relationship between rainfall and AR characteristics for regions at different distances from the AR major axis. (a) Region closest to AR (0-74 km on both sides from major axis), (b) the second-closest region (74-150 km on both sides from major axis), and (c) the region farthest away from AR (150-370 km on both sides from major axis). Shown is the average rainfall at different latitudes, and Spearman and Pearson correlation coefficients between rainfall (from stage IV) and IVT (from MERRA).

The region closest to the AR major axis is also the one characterized by the strongest relationship between IVT and rainfall. For this region, the correlation coefficients are quite large, in excess of 0.60 and up to 0.70 . These results suggest that there is a strong relationship between these two quantities, though its nature is not linear but monotonic (the values of the Spearman correlation coefficients are generally larger than the Pearson correlation coefficients). The strength of the relationship decreases in the regions farther away from the AR major axis (Figs. 9b,c).

Another research question we shed light on in this study involves the examination of the effects of AR duration on rainfall. We have three persistent ARs, two of which last six time steps and one that lasts five time steps. For each time step of the three ARs, the areal average rainfall $\pm 150 \mathrm{~km}$ around the major axis is calculated. With this, we can plot the rainfall amounts corresponding to each AR time step, allowing the examination of the effects of $\mathrm{AR}$ duration on rainfall amounts (Fig. 10). This figure suggests that the rainfall amounts are small at the early stage of the AR development. As the duration of the AR increases, so does the rainfall. The correlation coefficient between the AR time step and rainfall is 0.65 . The rainfall associated with the AR on 18 April consistently increased with time, while with the other two ARs it increased in the middle time steps followed by a decrease as the ARs subside. Although the dataset here is small, there is some indication of a positive relationship between rainfall and AR duration in the area close to AR major axis. A reasonable assumption is that this may be due the continuous supply of enhanced water vapor and unstable conditions sustaining mesoscale convective events (Houze 2014) leading to long periods of precipitation.

The final question of the study is related to the diurnal variation of $\mathrm{AR}$ occurrences and associated rainfall (Fig. 11). This is accomplished by considering the closest region around the AR major axis. We calculate the total rainfall from all the ARs at the 6-hourly reanalysis times (i.e., 0000, 0600, 1200, and 1800 UTC). For example, at 0600 UTC, five ARs are detected, and we calculate the total rainfall from all the five steps. We repeat this for the other three reanalysis time steps as well. Out of the 17 AR time steps, four occurred at 0000 UTC, five occurred at 0600 UTC, five occurred at 1200 UTC, and three occurred at 1800 UTC. Note that 0000 and 0600 UTC correspond to evening (1800 local time) and midnight hours (0000 local time), respectively, over the central United States. The relationship between IVT intensity and rainfall at each of the reanalysis times is also determined using Pearson and Spearman 


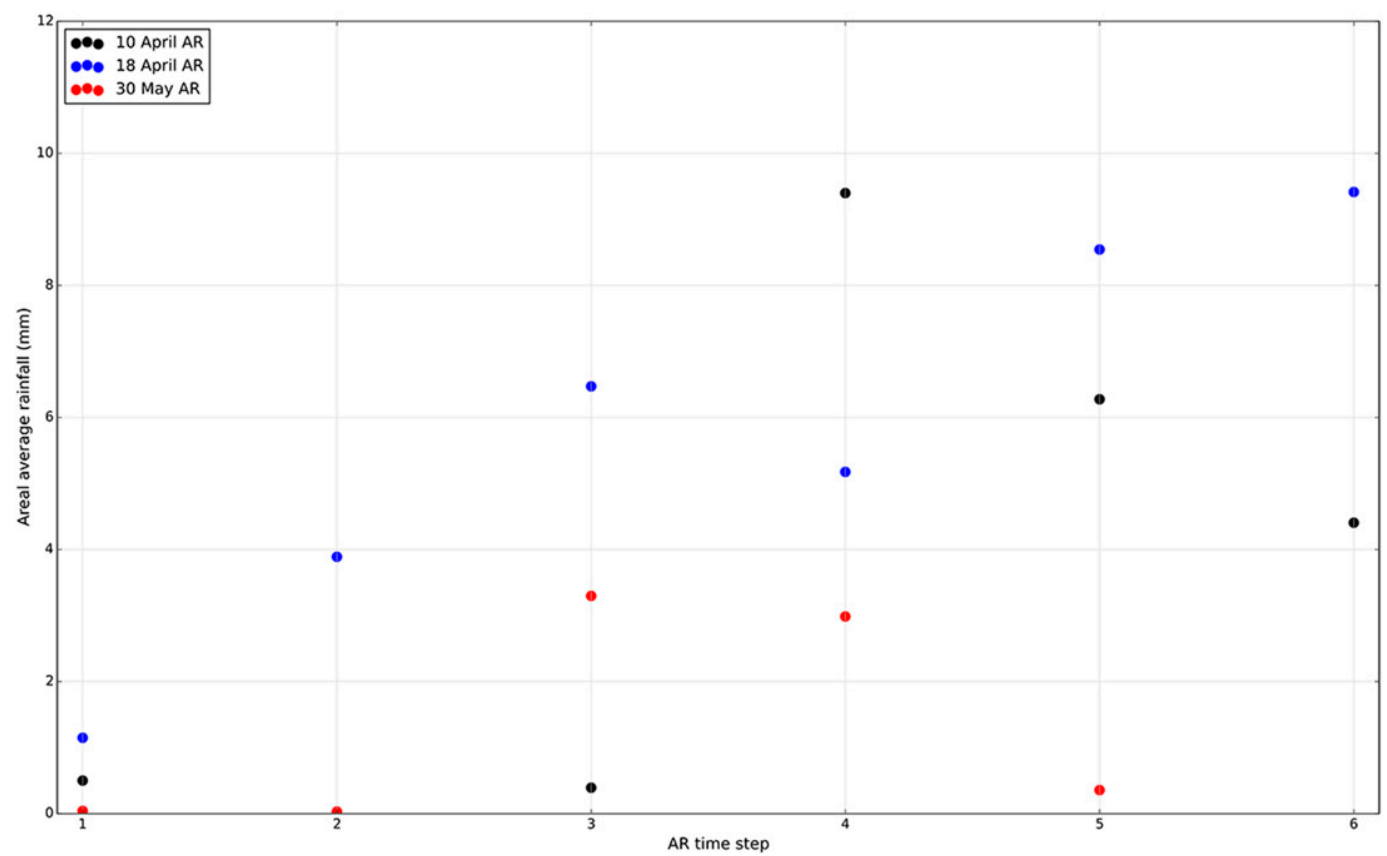

FIG. 10. Average rainfall around the AR major axis at different time steps of ARs. The rainfall values are computed from $40^{\circ}$ to $30.5^{\circ} \mathrm{N}$ within a $150-\mathrm{km}$ buffer from the AR major axis. The values on the $x$ axis refer to the duration of individual AR events: 1 means the first time step when the AR was identified, 2 means the consecutive second time step of AR condition, and so on.

correlation coefficients. Figure 11 is similar to Fig. 9, except that we focus on the four time steps and only on the region closest to the AR major axis. More rainfall is generally observed during the evening and midnight hours (Figs. 11a,b) compared to the rest of the day. This suggests that the diurnal cycle of the boundary layer, with its deep mixed layer in the afternoon initiating convection, followed by a stable nocturnal layer after sunset enhancing vapor transport, may be important factors for heavy rainfall associated with ARs (Arritt et al. 1997). Moreover, the rainfall amounts are higher at the midlatitude regions than at other latitudes during evening and midnight hours. The correlation between rainfall amounts and IVT intensity is not very strong at different times of the day. However, there is a strong relationship in the midlatitudes between $34^{\circ}$ and $37^{\circ} \mathrm{N}$ during all times of the day, with the exception of the midnight hours (0600 UTC) for which latitudes $37^{\circ}$ $38^{\circ} \mathrm{N}$ show a strong relationship. A strong monotonic relationship exists in the morning hours (1200 UTC) in the lower to midlatitudes from $32^{\circ}$ to $36^{\circ} \mathrm{N}$.

\section{Summary and conclusions}

The above analysis provides some basic characteristics of the relationship between ARs and the associated rainfall during IFloodS. Over the central United States, the IFloodS period (65 days from 10 April to 15 June 2013) was characterized by several heavy rainfall events, making it among the top five wettest 10 April to 15 June periods over a record of 66 years. About $50 \%$ of the accumulated rainfall during the IFloodS campaign was caused by only three ARs, highlighting the significant impact the ARs can have on the rainfall over the central United States.

Even though the occurrence of ARs is associated with heavy rainfall, this is not necessarily the case everywhere within the central United States. For instance, there is a region at the border between Iowa and Minnesota that received large rainfall amounts not related to ARs. More detailed analysis indicates that there were several days with daily rainfall accumulations smaller than $25 \mathrm{~mm}(\sim 1 \mathrm{in}$.). The largest daily rainfall accumulations (in excess of $100 \mathrm{~mm}$ ) occurred on 20 May 2013. The examination of the IVT maps for that day indicates that there were regions with IVT values exceeding our threshold. However, the length requirement (IVT exceeding the threshold from $40^{\circ}$ to $30.5^{\circ} \mathrm{N}$ ) was not satisfied. We visually inspected all the 6-hourly IVT maps and confirmed that the AR-identification algorithm we presented was able to capture the elongated nature of these events. Lagrangian trajectory analysis depicted the tropical and subtropical sources of the water vapor present in ARs. 

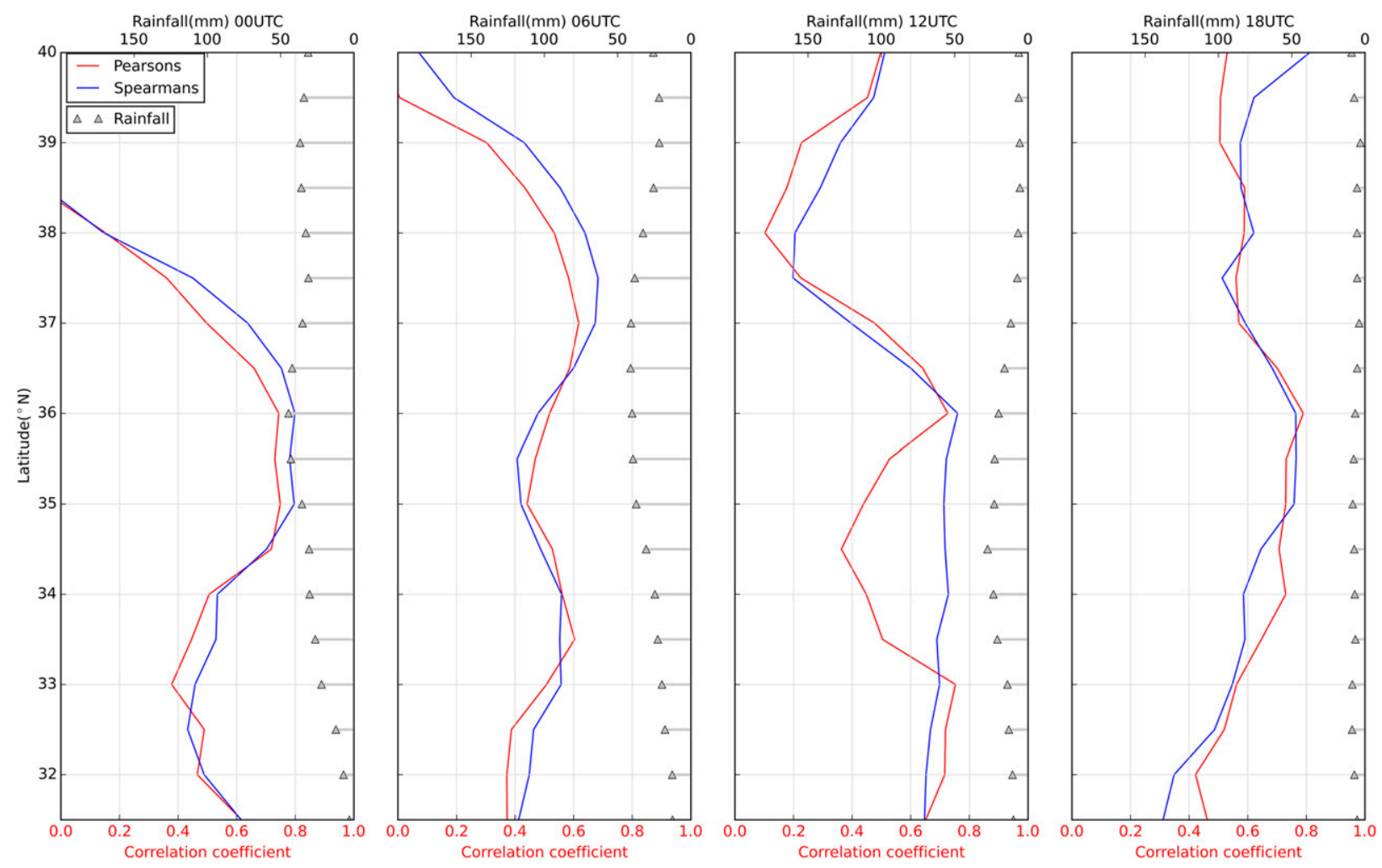

FIG. 11. As in Fig. 9, but for four times of a day: (a) 0000, (b) 0600, (c) 1200, and (d) 1800 UTC. Analyses are performed only for the region closest to the AR major axis.

Our evaluation of the different remote sensing products indicates that some of them are better suited than others in characterizing the rainfall associated with ARs. Our findings point to stage IV as the most suitable product. This statement reflects the higher accuracy of this product as well as its high spatial and temporal resolutions. This is also consistent with what is found by Villarini et al. (2011a) in characterizing rainfall associated with landfalling hurricanes in the United States. As far as satellite-based rainfall products are concerned, TRMM 3B42-V7 is the one that more closely reproduces the observational records.

Intense rainfall was associated with the three ARs that occurred during IFloodS. Long and narrow regions of intense rainfall along the major axes were present in the first two ARs and were caused by the ascent of warm and moist air along the cold fronts present during these ARs. During these three ARs, intense rainfall was mostly convective in nature, with warm and moist conditions sustained by the southerly advection in the ARs. During the third AR, unstable atmosphere with significant vertical wind shear (see in skew $T-\log p$ diagram in Fig. 7e where lower-level winds significantly change direction and magnitude from 950- to 850-hPa level) contributed to strong tornadoes over the U.S. Midwest during this AR.
Our analysis of the rainfall distribution for these events showed that much of the rainfall is located within about $100 \mathrm{~km}$ from the AR major axis, with rainfall amounts decreasing for increasing distance. The rainfall showed some latitudinal dependency, with more rainfall occurring at latitudes in the range of $34.5^{\circ}$ $37.5^{\circ} \mathrm{N}$. There is also strong positive monotonic relationship between IVT magnitude and rainfall amounts, especially in the region close to the AR major axis. In analyzing the effects of AR duration on rainfall, we find that there are small rainfall amounts in the early period of the AR lifetime, with substantial increases as these events develop and decreases as they come near to their end. Therefore, from an impact stand point, it would be useful to include a criterion of persistence in the AR detection algorithm as done, for instance, in Lavers and Villarini (2013b). Finally, we did not see any major diurnal dependence in the number of ARs; analysis related to the diurnal variation of AR rainfall suggested that rainfall was larger in nocturnal ARs.

This work and the results from the high-quality IFloodS data are useful for future studies on ARs and rainfall. As an example, given the presence of AR conditions during IFloodS and data from IFloodS, it is possible to model, or at least better understand, the 
horizontal and vertical structure of rainfall during ARs. One limitation of this analysis is related to the small number of events we analyzed. Here we focused on a period of 65 days, which is not long enough to make any climatological claims regarding ARs and the associated rainfall. However, with this caveat in mind, this dataset does suggest possible relationships between AR and rainfall characteristics. In its essence, this study paves the way for a number of research questions that will be answered in the future using longer records.

Acknowledgments. Munir A. Nayak was supported by NASA Headquarters under the NASA Earth and Space Science Fellowship Program, Grant NNX14AK78H. Gabriele Villarini acknowledges financial support from the USACE Institute for Water Resources, IIHRHydroscience and Engineering, and the Iowa Flood Center. Valuable help from and insightful discussions with Dr. David Lavers and comments by five anonymous reviewers are gratefully acknowledged.

\section{REFERENCES}

Anderson, C. J., and R. W. Arritt, 2001: Mesoscale convective systems over the United States during the 1997-98 El Niño. Mon. Wea. Rev., 129, 2443-2457, doi:10.1175/1520-0493(2001)129<2443: MCSOTU>2.0.CO;2.

Arritt, R. W., T. D. Rink, M. Segal, D. P. Todey, C. A. Clark, M. J. Mitchell, and K. M. Labas, 1997: The Great Plains low-level jet during the warm season of 1993. Mon. Wea. Rev., 125, 2176-2192, doi:10.1175/1520-0493(1997)125<2176:TGPLLJ >2.0.CO;2.

Bonner, W. D., 1968: Climatology of the low level jet. Mon. Wea. Rev., 96, 833-850, doi:10.1175/1520-0493(1968)096<0833: COTLLJ $>2.0 . \mathrm{CO} ; 2$.

Browning, K. A., 1997: The dry intrusion perspective of extratropical cyclone development. Meteor. Appl., 4, 317-324, doi:10.1017/S1350482797000613.

Budikova, D., J. S. M. Coleman, S. A. Strope, and A. Austin, 2010: Hydroclimatology of the 2008 Midwest floods. Water Resour. Res., 46, W12524, doi:10.1029/2010WR009206.

Carlson, T. N., 1980: Airflow through midlatitude cyclones and the comma cloud pattern. Mon. Wea. Rev., 108, 1498-1509, doi:10.1175/1520-0493(1980)108<1498:ATMCAT>2.0.CO;2.

Catto, J. L., L. C. Shaffrey, and K. I. Hodges, 2010: Can climate models capture the structure of extratropical cyclones? J. Climate, 23, 1621-1635, doi:10.1175/2009JCLI3318.1.

Dee, D. P., and Coauthors, 2011: The ERA-Interim reanalysis: Configuration and performance of the data assimilation system. Quart. J. Roy. Meteor. Soc., 137, 553-597, doi:10.1002/ qj.828.

Dettinger, M. D., 2013: Atmospheric rivers as drought busters on the U.S. West Coast. J. Hydrometeor., 14, 1721-1732, doi:10.1175/JHM-D-13-02.1.

— , F. M. Ralph, T. Das, P. J. Neiman, and D. R. Cayan, 2011: Atmospheric rivers, floods and the water resources of California. Water, 3, 445-478, doi:10.3390/w3020445.

Dirmeyer, P. A., and J. L. Kinter III, 2009: The "Maya Express": Floods in the U.S. Midwest. Eos, Trans. Amer. Geophys. Union, 90, 101-102, doi:10.1029/2009EO120001.
— and - 2010: Floods over the U.S. Midwest: A regional water cycle perspective. J. Hydrometeor., 11, 1172-1181, doi:10.1175/2010JHM1196.1.

Draxler, R. R., and G. D. Rolph, 2015: HYSPLIT: Hybrid SingleParticle Lagrangian Integrated Trajectory Model. NOAA ARL READY, accessed 3 May 2015. [Available online at http://www.arl.noaa.gov/HYSPLIT.php.]

Higgins, R. W., W. Shi, E. Yarosh, and R. J. Joyce, 2000: Improved United States precipitation quality control system and analysis. NOAA/CPC Atlas 7, 40 pp.

Hou, A. Y., and Coauthors, 2014: The Global Precipitation Measurement Mission. Bull. Amer. Meteor. Soc., 95, 701-722, doi:10.1175/BAMS-D-13-00164.1.

Houze, R. A., Jr., 2014: Cloud Dynamics. 2nd ed. International Geophysics Series, Vol. 104, Academic Press, 496 pp.

Huffman, G. J., and Coauthors, 2007: The TRMM Multisatellite Precipitation Analysis (TMPA): Quasi-global, multiyear, combined-sensor precipitation estimates at fine scales. J. Hydrometeor., 8, 38-55, doi:10.1175/JHM560.1.

Joyce, R. J., J. E. Janowiak, P. A. Arkin, and P. Xie, 2004: CMORPH: A method that produces global precipitation estimates from passive microwave and infrared data at high spatial and temporal resolution. J. Hydrometeor., 5, 487-503, doi:10.1175/1525-7541(2004)005<0487:CAMTPG > 2.0.CO;2.

Kunkel, K. E., S. A. Changnon, and J. R. Angel, 1994: Climatic aspects of the 1993 upper Mississippi river basin flood. Bull. Amer. Meteor. Soc., 75, 811-822, doi:10.1175/1520-0477(1994)075<0811: CAOTUM $>2.0 . \mathrm{CO} ; 2$.

Lavers, D. A., and G. Villarini, 2013a: The nexus between atmospheric rivers and extreme precipitation across Europe. Geophys. Res. Lett., 40, 3259-3264, doi:10.1002/grl.50636.

— central United States. J. Climate, 26, 7829-7836, doi:10.1175/ JCLI-D-13-00212.1.

- , and $-2015 \mathrm{a}$ : The contribution of atmospheric rivers to precipitation in Europe and the United States. J. Hydrol., 522, 382-390, doi:10.1016/j.jhydrol.2014.12.010.

$\longrightarrow$, and,$- 2015 \mathrm{~b}$ : The relationship between daily European precipitation and measures of atmospheric water vapour transport. Int. J. Climatol., 35, 2187-2192, doi:10.1002/ joc.4119.

_ , R. P. Allan, E. F. Wood, G. Villarini, D. J. Brayshaw, and A. J. Wade, 2011: Winter floods in Britain are connected to atmospheric rivers. Geophys. Res. Lett., 38, L23803, doi:10.1029/ 2011 GL049783.

_ , G. Villarini, R. P. Allan, E. F. Wood, and A. J. Wade, 2012: The detection of atmospheric rivers in atmospheric reanalyses and their links to British winter floods and the large-scale climatic circulation. J. Geophys. Res., 117, D20106, doi:10.1029/ 2012JD018027.

Lin, Y., and K. E. Mitchell, 2005: The NCEP stage II/IV hourly precipitation analyses: Development and applications. Proc. 19th Conf. on Hydrology, San Diego, CA, Amer. Meteor. Soc., 1.2. [Available online at https://ams.confex.com/ams/ Annual2005/techprogram/paper_83847.htm.]

Maddox, R. A., C. F. Chappell, and L. R. Hoxit, 1979: Synoptic and meso- $\alpha$ scale aspects of flash flood events. Bull. Amer. Meteor. Soc., 60, 115-123, doi:10.1175/1520-0477-60.2.115.

McMurdie, W. L., and R. A. Houze, 2006: Weather systems. Atmospheric Science, 2nd ed. J. M. Wallace, and P. V. Hobbs, Eds., Academic Press, 313-373.

Moore, B. J., P. J. Neiman, F. M. Ralph, and F. E. Barthold, 2012: Physical processes associated with heavy flooding rainfall in 
Nashville, Tennessee, and vicinity during 1-2 May 2010: The role of an atmospheric river and mesoscale convective systems. Mon. Wea. Rev., 140, 358-378, doi:10.1175/ MWR-D-11-00126.1.

Moore, J. T., F. H. Glass, C. E. Graves, S. M. Rochette, and M. J. Singer, 2003: The environment of warm-season elevated thunderstorms associated with heavy rainfall over the central United States. Wea. Forecasting, 18, 861-878, doi:10.1175/ 1520-0434(2003)018<0861:TEOWET $>2.0$. CO;2.

Nakamura, J., U. Lall, Y. Kushnir, A. W. Robertson, and R. Seager, 2013: Dynamical structure of extreme floods in the U.S. Midwest and the United Kingdom. J. Hydrometeor., 14, 485-504, doi:10.1175/JHM-D-12-059.1.

Nayak, M. A., G. Villarini, and D. A. Lavers, 2014: On the skill of numerical weather prediction models to forecast atmospheric rivers over the central United States. Geophys. Res. Lett., 41 , 4354-4362, doi:10.1002/2014GL060299.

Neiman, P. J., F. M. Ralph, G. A. Wick, J. D. Lundquist, and M. D. Dettinger, 2008: Meteorological characteristics and overland precipitation impacts of atmospheric rivers affecting the west coast of North America based on eight years of SSM/I satellite observations. J. Hydrometeor., 9, 22-47, doi:10.1175/ 2007JHM855.1.

-, G. A. Wick, B. J. Moore, F. M. Ralph, J. R. Spackman, and B. Ward, 2014: An airborne study of an atmospheric river over the subtropical Pacific during WISPAR: Dropsonde budgetbox diagnostics and precipitation impacts in Hawaii. Mon Wea. Rev., 142, 3199-3223, doi:10.1175/MWR-D-13-00383.1.

Newell, R. E., and Y. Zhu, 1994: Tropospheric rivers: A one-year record and a possible application to ice core data. Geophys. Res. Lett., 21, 113-116, doi:10.1029/93GL03113.

- , N. E. Newell, Y. Zhu, and C. Scott, 1992: Tropospheric rivers?-A pilot study. Geophys. Res. Lett., 19, 2401-2404, doi:10.1029/92GL02916.

Ralph, F. M., P. J. Neiman, and G. A. Wick, 2004: Satellite and CALJET aircraft observations of atmospheric rivers over the eastern North Pacific Ocean during the winter of 1997/98. Mon Wea. Rev., 132, 1721-1745, doi:10.1175/1520-0493(2004)132<1721: $\mathrm{SACAOO}>2.0 . \mathrm{CO} ; 2$

, S. I. Gutman, M. D. Dettinger, D. R. Cayan, and A. B. White, 2006: Flooding on California's Russian River: Role of atmospheric rivers. Geophys. Res. Lett., 33, L13801, doi:10.1029/2006GL026689.
T. Coleman, P. J. Neiman, R. J. Zamora, and M. D. Dettinger, 2013: Observed impacts of duration and seasonality of atmospheric-river landfalls on soil moisture and runoff in coastal Northern California. J. Hydrometeor., 14, 443-459, doi:10.1175/JHM-D-12-076.1.

Rienecker, M. M., and Coauthors, 2011: MERRA: NASA's ModernEra Retrospective Analysis for Research and Applications. J. Climate, 24, 3624-3648, doi:10.1175/JCLI-D-11-00015.1.

Rutz, J. J., W. J. Steenburgh, and F. M. Ralph, 2014: Climatological characteristics of atmospheric rivers and their inland penetration over the western United States. Mon. Wea. Rev., 142, 905-921, doi:10.1175/MWR-D-13-00168.1.

Schultz, D. M., 2001: Reexamining the cold conveyor belt. Mon. Wea. Rev., 129, 2205-2225, doi:10.1175/1520-0493(2001)129<2205: $\mathrm{RTCCB}>2.0 . \mathrm{CO} ; 2$.

Schumacher, R. S., and R. H. Johnson, 2005: Organization and environmental properties of extreme-rain-producing mesoscale convective systems. Mon. Wea. Rev., 133, 961-976, doi:10.1175/MWR2899.1.

- and - 2006: Characteristics of U.S. extreme rain events during 1999-2003. Wea. Forecasting, 21, 69-85, doi:10.1175/ WAF900.1.

Smith, J. A., M. L. Baeck, G. Villarini, D. B. Wright, and W. Krajewski, 2013: Extreme flood response: The June 2008 flooding in Iowa. J. Hydrometeor., 14, 1810-1825, doi:10.1175/JHM-D-12-0191.1.

Sorooshian, S., K.-L. Hsu, X. Gao, H. V. Gupta, B. Imam, and D. Braithwaite, 2000: Evaluation of PERSIANN system satellite-based estimates of tropical rainfall. Bull. Amer. Meteor. Soc., 81, 2035-2046, doi:10.1175/1520-0477(2000)081<2035: EOPSSE $>2.3 . \mathrm{CO} ; 2$.

Stevenson, S. N., and R. S. Schumacher, 2014: A 10-year survey of extreme rainfall events in the central and eastern United States using gridded multisensor precipitation analyses. Mon. Wea. Rev., 142, 3147-3162, doi:10.1175/MWR-D-13-00345.1.

Villarini, G., J. A. Smith, M. L. Baeck, T. Marchok, and G. A. Vecchi, 2011a: Characterization of rainfall distribution and flooding associated with U.S. landfalling tropical cyclones: Analyses of Hurricanes Frances, Ivan, and Jeanne (2004). J. Geophys. Res., 116, D23116, doi:10.1029/2011JD016175.

, R. Vitolo, D. B. Stephenson, and W. F. Krajewski, 2011b: On the frequency of heavy rainfall for the Midwest of the United States. J. Hydrol., 400, 103-120, doi:10.1016/ j.jhydrol.2011.01.027. 